\title{
PENGARUH RETURN ON ASSETS (ROA), RETURN ON EQUITY (ROE), DEBT EQUITY RATIO (DER), DAN PRICE EARNINGS RATIO (PER) TERHADAP RETURN SAHAM PERUSAHAAN CONSUMER GOODS
}

\author{
Dora Gunawan \\ Program Studi Magister Manajemen Universitas Tarumanagara \\ doragunawan10@gmail.com \\ Indra Widjaja \\ Program Studi Magister Manajemen Universitas Tarumanagara \\ Masuk : 03-12-2020, revisi : 15-12-2020, diterima untuk diterbitkan : 16-12-2020
}

\begin{abstract}
The purpose of this study was to determine the effect of Return on Assets (ROA), Return on Equity (ROE), Debt Equity Ratio (DER), and Price Earnings Ratio (PER) on stock returns of consumer goods companies. The data in this study were taken from 10 consumer goods companies listed on the Indonesia Stock Exchange. The research period is 4 years, namely 2017 until the second quarter of 2020. The method used in this study is to compare the elements in the financial statements. In this study, the method used to analyze the data is multiple linear regression and hypothesis testing between the dependent variable and the independent variable. ROA, ROE, DER, and PER are independent variables, and stock returns are the dependent variable. Based on hypothesis testing, it can be concluded that ROA and DER have a significant positive effect on stock returns. ROE has a significant negative effect on stock returns. And PER has no significant effect on stock returns. While collectively all variables have a significant effect on stock returns. By knowing financial performance as an indicator for investors before investing in the capital market, fundamental analysis is still an effective tool for investors in selecting stocks.
\end{abstract}

Keywords: Return on Assets (ROA), Return on Equity (ROE), Debt Equity Ratio (DER), Price Earnings Ratio (PER), Stock Return

Abstrak: Tujuan dari penelitian ini adalah untuk mengetahui pengaruh Return on Assets (ROA), Return on Equity (ROE), Debt Equity Ratio (DER), dan Price Earnings Ratio (PER) terhadap return saham perusahaan barang konsumsi. Data dalam penelitian ini diambil dari 10 perusahaan consumer goods yang terdaftar di Bursa Efek Indonesia. Periode penelitian selama 4 tahun yaitu tahun 2017 sampai dengan triwulan II tahun 2020. Metode yang digunakan dalam penelitian ini adalah membandingkan unsur-unsur pada laporan keuangan. Dalam penelitian ini metode yang digunakan untuk menganalisis data yaitu regresi linier berganda dan pengujian hipotesis antara variabel dependen dan variabel independen. ROA, ROE, DER dan PER adalah variabel independen, dan return saham sebagai variabel dependen. Berdasarkan pengujian hipotesis, diperoleh hasil yang dapat disimpulkan bahwa ROA dan DER berpengaruh signifikan positif terhadap return saham. ROE berpengaruh signifikan negatif terhadap return saham. Dan PER tidak berpengaruh signifikan terhadap return saham. Sedangkan secara bersama-sama semua variabel berpengaruh signifikan terhadap return saham. Dengan mengetahui kinerja keuangan sebagai indikator bagi investor sebelum berinvestasi di pasar modal, maka analisis fundamental masih menjadi salah satu alat yang efektif bagi investor dalam memilih saham.

Kata Kunci : Return on Assets (ROA), Return on Equity (ROE), Debt Equity Ratio (DER), Price Earnings Ratio (PER), Stock Return 


\section{PENDAHULUAN}

Jumlah penduduk Indonesia (2019) berjumlah 261 juta jiwa, namun hanya sekitar 0.4 persen dari total jumlah penduduk Indonesia yang menjadi investor domestik di pasar modal Indonesia. Berdasarkan data yang tersimpan di Kustodian Sentral Efek Indonesia (KSEI) per Desember 2018 tercatat 52,17\% investor asing menguasai pasar modal Indonesia, dan 47,83\% adalah investor domestik. Ketika terjadi pengalihan dana dari pasar modal Indonesia oleh pemodal asing, maka. pasar modal Indonesia juga akan terjatuh. Oleh karena itu memiliki bekal pengetahuan yang cukup untuk terjun dalam transaksi di pasar modal sangat diperlukan. Pengetahuan dalam menganalisa pasar keuangan bukan hanya untuk mendapatkan imbal hasil (stock return) yang maksimal namun juga meminimalkan resiko dalam berinvestasi.

Salah satu sektor saham yang banyak dicari para pemodal yaitu sektor consumer goods. Biasanya saham sektor ini memiliki prospek yang bagus dalam jangka panjang. Hal ini disebabkan produk barang konsumsi cenderung digunakan secara terus menerus, sehingga permintaan akan produk tersebut bersifat stabil dan bagus dalam jangka panjang.

Pemodal di pasar modal sanga. mempedulikan kemampuan perusahaan untuk menghasilkan laba. Rasio profitabilitas yang menjelaskan tingkat pengembalian asset yang dipunyai untuk menghasilkan laba yaitu Return on Assets (ROA). Faktor penting yang juga perlu diperhatikan oleh investor saham yaitu tingkat pengembalian investasi. Rasio rentabilitas dapat dipakai untuk menjelaskan tingkat pengembalian investasi yaitu Return on Equity (ROE). Untuk menganalisa tingkat resiko, maka investor dapat menggunakan Debt Equity Ratio (DER) sebagai alat analisa. Investor juga harus mampu menilai harga wajar apabila dibandingkan dengan tingkat pengembalian investasi sebelum berinvestasi. Rasio pasar yang dapat memberikan penjelasan untuk pengambilan keputusan investasi saham yaitu Price Earnings Ratio (PER).

\section{TINJAUAN PUSTAKA}

\section{Penelitian Terdahulu}

Terdapat beberapa penelitian terdahulu mengenai pengaruh ROA, ROE, DER,dan PER terhadap return saham yaitu:

a. Araújo dan Machado (2018) menunjukkan B/M Ratio dan ROE mempunyai pengaruh yang signifikan dan arah hubungan positif terhadap dalam memprediksi imbal hasil suatu saham.

b. Aloui dan Jarboui (2018) berpendapat bahwa return saham dipengaruhi secara signifikan dan arah hubungan negatif dari ROA. Namun return saham dipengaruhi secara signifikan dan positif dari CEO, audit size, dan DER.

c. Menurut Heryanto (2016) bahwa untuk mengukur profitabilitas (yang diwakili oleh variabel ROA) membawa pengaruh positif dan signifikan dalam memprediksi return saham.

d. Penelitian yang dilakukan oleh di Bombay Stock Exchange's Index oleh Pradeep dan Hariharan (2019) ditemukan bahwa PER dan PBV berpengaruh negatif dan signifikan terhadap imbal hasil saham. Dan imbal hasil saham dipengaruhi secara positif dan signifikan dari EPSnya.

\section{Rasio Analisis}

\section{Return on Asset (ROA)}

ROA adalah salah satu rasio profitabilitas yang memperlihatkan berapa besar keuntungan yang didapat dari asset yang dimiliki perusahaan (Filbert \& Prasetya, 2017, p. 115).

\section{Return on Equity (ROE)}

ROE adalah salah satu rasio profitabilitas yang menginformasikan berapa keuntungan dari investasi ekuitas yang sudah diserahkan pada suatu perusahaan (Filbert \& Prasetya, 2017, p. 113). 


\section{Debt Equity Ratio (DER)}

DER adalah salah satu rasio solvabilitas yang digunakan untuk mengetahui berapa besar hutang yang dimiliki perusahaan bila dibandingkan dengan ekuitasnya (Filbert \& Prasetya, 2017, p. 80).

\section{Price Earnings Ratio (PER)}

PER adalah salah satu rasio dalam menghitung nilai valuasi atas harga saham (Filbert \& Prasetya, 2017, p. 151).

\section{Return Saham}

Return saham merupakan salah satu faktor yang memotivasi investor berinvestasi dan juga merupakan imbalan atas keberanian investor menanggung resiko atas investasi yang dilakukannya (Tandelilin, 2010, p. 102).

\section{METODOLOGI}

\section{Variabel Penelitian dan Operasional Variabel}

Dari perumusan masalah pada penelitian ini, maka variabel yang akan diteliti yaitu:

1. $\mathrm{X}_{1}=$ Return On Assets $(\mathrm{ROA})$

2. $\mathrm{X}_{2}=$ Return On Equity (ROE)

3. $\mathrm{X}_{3}=$ Debt Equity Ratio (DER)

4. $\mathrm{X}_{4}=$ Price Earnings Ratio (PER)

5. $\mathrm{Y}=$ Return Saham

Tabel 1

Operasional Variabel

\begin{tabular}{|c|c|c|}
\hline No. & Variabel & Pengukuran \\
\hline $\mathrm{X}_{1}$ & Return On Assets (ROA) & ROA =(Laba bersih (setelah pajak) $/$ Total asset) $\mathrm{x} \mathrm{100 \%}$ \\
\hline $\mathrm{X}_{2}$ & Return On Equity (ROE) & ROE = (Laba bersih (setelah pajak) / Ekuitas pemegang saham) $\mathrm{x} 100 \%$ \\
\hline $\mathrm{X}_{3}$ & Debt Equity Ratio (DER) & DER = (Total hutang / Ekuitas pemegang saham) $\mathrm{x} 100 \%$ \\
\hline $\mathrm{X}_{4}$ & Price Earnings Ratio $(\mathrm{PER})$ & $\mathrm{PER}=$ Harga saham saat itu / keuntungan per lembar saham \\
\hline $\mathrm{Y}$ & Return Saham & Return saham $=\mathrm{P}_{1}-\mathrm{P}_{0} / \mathrm{P}_{0}$ \\
\hline
\end{tabular}

\section{Data sampel dan Penggunaan Uji}

Penelitian ini menggunakan 10 perusahaan consumer goods. Perusahaan tersebut sudah tercatat di bursa efek, dalam periode waktu 2017 sampai dengan 4 tahun ke depan. Semua variabel dilakukan penghitungan operasional terlebih dahulu. Setelah diperoleh hasil kemudian diuji regresinya secara linier dan berganda, dengan menggunakan SPSS 25.

\section{HASIL PENELITIAN}

Hasil pengolahan data yang dianalisis oleh SPSS 25, untuk hasil uji $F$ dan uji t yaitu sebagai berikut:

\section{Tabel 2}

Hasil Uji F

ANOVA $^{\mathrm{a}}$

\begin{tabular}{|c|c|c|c|c|c|c|}
\hline \multicolumn{2}{|c|}{ Model } & Sum of Squares & df & Mean Square & F & Sig. \\
\hline \multirow{3}{*}{1} & Regression & 2026,779 & 4 & 506,695 & 95,627 &, $000^{\mathrm{b}}$ \\
\cline { 2 - 8 } & Residual & 715,317 & 135 & 5,299 & & \\
\cline { 2 - 8 } & Total & 2742,096 & 139 & & & \\
\hline
\end{tabular}

Pada tabel 2, Jika seluruh variabel bebas (X) diregresikan secara agregrat terhadap variabel terikatnya (Y), maka dapat disimpulkan memiliki pengaruh signifikansi. Terbukti dari nilai nilai $F_{\text {hitung }}>F_{\text {tabel }}(95.627>2.66)$. Dan signifikansi berada tidak lebih besar dari 0.005, yaitu 0.000 . Sehingga dapat ditarik kesimpulan bahwa return saham dapat dipengaruhi secara signifikan jika seluruh variabel bebas $(\mathrm{X})$ diregresikan dengan bersama-sama. 
Tabel 3

\section{Hasil Uji t}

Coefficients $^{\mathrm{a}}$

\begin{tabular}{|c|c|c|c|c|c|c|}
\hline \multirow{2}{*}{\multicolumn{2}{|c|}{ Model }} & \multicolumn{2}{|c|}{$\begin{array}{c}\text { Unstandardized } \\
\text { Coefficients }\end{array}$} & \multirow{2}{*}{$\begin{array}{c}\text { Standardized } \\
\text { Coefficients }\end{array}$} & \multirow[t]{2}{*}{$\mathrm{t}$} & \multirow[t]{2}{*}{ Sig. } \\
\hline & & B & Std. Error & & & \\
\hline \multirow{5}{*}{1} & $($ Constant $)$ & $-0,036$ & 0,518 & & $-0,070$ & 0,944 \\
\hline & ROA & 0,150 & 0,051 & 0,265 & 2,947 & 0,004 \\
\hline & ROE & $-0,065$ & 0,017 & $-0,327$ & $-3,778$ & 0,000 \\
\hline & DER & 0,922 & 0,055 & 0,788 & 16,650 & 0,000 \\
\hline & PER & $-0,007$ & 0,007 & $-0,056$ & $-1,130$ & 0,261 \\
\hline
\end{tabular}

Persamaan regresi secara linier berganda yang dapat disusun, berdasarkan hasil pengamatan tabel 3:

$$
Y=-0.036+0.150 X_{1}-0.065 X_{2}+0.922 X_{3}-0.007 X_{4}
$$

Jika seluruh variabel bebas $(X)$ diregresikan secara terpisah terhadap variabel terikatnya (Y), ditemukan hanya PER yang tidak memiliki pengaruh dalam memprediksi imbal hasil saham (signifikansi $=0.261>0.05$ ). Sedangkan 3 variabel lainnya $(\mathrm{ROA}, \mathrm{ROE}, \mathrm{DER})$ memiliki signifikansi yang tidak lebih besar dari 0.05 .

Karena pada penelitian ini ditemukan ROA memiliki arah hubungan yang positif dan memberi pengaruh signifikan terhadap return saham, maka ditemukan bahwa setiap perubahan ROA maka akan membawa perubahan juga terhadap return saham. Dengan demikian pemodal dapat memprediksi imbal hasil yang akan diterimanya, dengan melihat kemampuan perusahaan dalam mengolah asetnya untuk mendatangkan laba. Jika ROA tidak semakin kecil, maka return saham yang diterimanya besar, demikian pula sebaliknya.

ROE dalam penelitian ini ditemukan memiliki arah hubungan yang negatif namun memberi pengaruh yang signifikan terhadap return saham. Artinya dalam ada arah hubungan yang berbeda arah ketika terjadi peningkatan ekuitas terhadap imbal hasil saham. Hal ini dikarenakan adanya anomali sampel penelitan (dipilih berdasarkan likuiditas), selain itu adanya faktor lain yang lebih diandalkan para pemodal ketika pengambilan keputusan investasi.

Variabel yang paling unggul di dalam penelitian ini adalah DER. Dengan arah hubungan positif yang paling tinggi dan bersignifikan terhadap return saham, maka investor dapat mempertimbangkan DER sebagai variabel acuan dalam pengambilan keputusan.

Namun pada penelitian ini ditemukan hanya PER yang tidak memiliki pengaruh yang signifikan dan juga memiliki arah hubungan negatif dengan return saham. Hal ini disebabkan PER lebih banyak berhubungan dengan faktor-faktor lain yang menjadi penentu ketika pemodal akan bertindak dalam memutuskan kegiatan investasinya.

\section{KESIMPULAN}

Setelah penulis menyelesaikan penelitian di atas, maka hasil dari analisis dan kesimpulan yang dapat ditemukan adalah:

1. Pengaruh keempat variabel bebas dalam penelitian $(\mathrm{X})$ terhadap variabel terikatnya $(\mathrm{Y})$ :

a. ROA memiliki hubungan dengan arah yang positif dan memberi pengaruh signifikan terhadap return saham.

b. ROE memiliki hubungan dengan arah yang negatif dan memberi pengaruh signifikan terhadap return saham.

c. DER memiliki hubungan dengan arah yang positif dan memberi pengaruh signifikan terhadap return saham.

d. PER memiliki hubungan dengan arah yang negatif namun tidak signifikan terhadap return saham. 
2. Dalam penelitian ini terungkap DER merupakan variabel yang paling unggul jika dibandingkan dengan variabel bebas lainnya.

3. Dalam penelitian ini terungkap PER belum dapat dijadikan acuan dalam memperhitungkan imbal hasil saham.

\section{DAFTAR PUSTAKA}

Aloui, M., \& Jarboui, A. (2018). The effects of corporate governance on the stock return volatility: During the financial crisis. International Journal of Law and Management, 60(2), 478-495. https://doi.org/10.1108/IJLMA-01-2017-0010

Araújo, R. C. da C., \& Machado, M. A. V. (2018). Book-to-market ratio, return on equity and Brazilian stock returns. RAUSP Management Journal, 53(3), 324-344. https://doi.org/10.1108/RAUSP-04-2018-001

Filbert, R., \& Prasetya, W. (2017). Investasi saham ala fundamentalis dunia. Elex Media Komputindo.

Heryanto. (2016). Effect of liquidity and profitability to bank stock return in Indonesia Stock Exchange (IDX). International Journal of Academic Research in Accounting, Finance and Management Sciences, 6(3), 131-138. https://doi.org/10.6007/ijarafms/v6-i3/2219

Pradeep, K. V., \& Hariharan, S. (2019). Effect of valuation and growth: Stock market returns. SCMS Journal of Indian Management, 16(1), 33-42.

Tandelilin, E. (2010). Portofolio dan investasi teori dan aplikasi. Kanisius. 